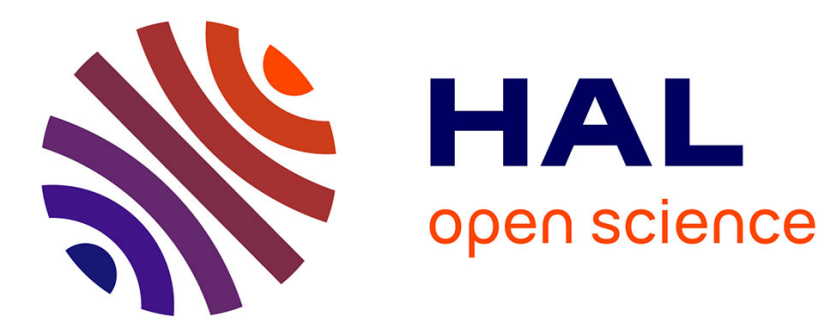

\title{
Genetic differentiation of urban populations of Euglossa cordata from the state of São Paulo, Brazil
}

\author{
Natália Cerântola, Cíntia Oi, Marcelo Cervini, Marco Lama
}

\section{To cite this version:}

Natália Cerântola, Cíntia Oi, Marcelo Cervini, Marco Lama. Genetic differentiation of urban populations of Euglossa cordata from the state of São Paulo, Brazil. Apidologie, 2011, 42 (2), pp.214-222. 10.1051/apido/2010055 . hal-01003590

\section{HAL Id: hal-01003590 \\ https://hal.science/hal-01003590}

Submitted on 1 Jan 2011

HAL is a multi-disciplinary open access archive for the deposit and dissemination of scientific research documents, whether they are published or not. The documents may come from teaching and research institutions in France or abroad, or from public or private research centers.
L'archive ouverte pluridisciplinaire HAL, est destinée au dépôt et à la diffusion de documents scientifiques de niveau recherche, publiés ou non, émanant des établissements d'enseignement et de recherche français ou étrangers, des laboratoires publics ou privés. 


\title{
Genetic differentiation of urban populations of Euglossa cordata from the state of São Paulo, Brazil*
}

\author{
Natália de Campos Muradas CerÂNTOLA ${ }^{1}$, Cíntia Akemi OI ${ }^{1}$, Marcelo CERvinI ${ }^{2}$, \\ Marco Antonio DEL LAMA ${ }^{1}$ \\ ${ }^{1}$ Laboratório de Genética Evolutiva de Himenópteros, Departamento de Genética e Evolução, Universidade \\ Federal de São Carlos, Rodovia Washington Luiz km 235, 13565.905, São Carlos, São Paulo, Brazil \\ ${ }^{2}$ Laboratório de Imunogenética - DNA, Departamento de Genética e Evolução, Universidade Federal de São \\ Carlos, Rodovia Washington Luiz km 235, 13565.905, São Carlos, São Paulo, Brazil
}

Received 14 December 2009 - Revised 4 May 2010 - Accepted 5 May 2010

\begin{abstract}
Males and females of Euglossa cordata collected inside flowers of Thevetia peruviana in urban areas of eleven cities of the state of São Paulo were analysed using allozymes and nine microsatellite loci. The analyses revealed that these populations have a high genetic diversity and are under genetic equilibrium, showing low population structuring and rare diploid males; consequently, high gene flow and effective population size $(\mathrm{Ne})$ are inferred. These findings corroborate previous biological observations and phylogeographic evidence that report dispersion over long distances of Euglossini species in South America.
\end{abstract}

genetic diversity / gene flow / euglossine bees / microsatellites / allozymes

\section{INTRODUCTION}

Euglossini bees, or "orchid bees" (Hymenoptera: Apidae: Euglossini), have an exclusively Neotropical distribution (Búrquez, 1997) and are important pollinators of many angiosperm species (Cancine and Damon, 2007; Guimarães et al., 2008). More than 200 species were described before 2002 (Ramírez et al., 2002) and new species have recently been identified (Oliveira and Nemésio, 2003; Oliveira, 2006).

Some Euglossini species are common in urban habitats (López-Uribe et al., 2008), where gardens and parks provide resources like nectar, pollen and nesting sites during the entire year. Natural habitats have suffered drastic disturbances in the last years and, consequently, cities have increasingly been used as a refuge

Corresponding author: M.A. Del Lama, dmdl@ufscar.br

* Manuscript editor: Marina Meixner by some species of bees. Therefore, it is important to verify the genetic health and viability of the populations established in these environments (Grixti et al., 2009).

Euglossini males and females have great flight capacity (Roubik and Hanson, 2004). Adults travel for more than $50 \mathrm{~km}$ in a search for nectar or floral fragrances that they use for sexual attraction (Janzen, 1971; Dressler, 1982; Eltz et al., 2003). This ability to fly over long distances allows high dispersal of these bees, which avoids inbred mating. However, some studies revealed that Euglossa cordata Linnaeus 1758 females collect nectar (López-Uribe et al., 2008) and reuse the natal nest or a nest next to it (Garófalo, 1992), suggesting that these females have philopatric behaviour.

Although Euglossini encompass a large number of species, information on them is scarce and based mostly on data obtained from males collected with artificial baits (Sandino, 2004; Farias et al., 2008; Rasmussen, 2009). 
Because such compounds do not equally attract different species, this sampling strategy can produce biased inferences about species distribution because the samples do not reflect the abundance and species richness in the studied sites (López-Uribe et al., 2008). By analysing only males of a population, we may generate erroneous inferences about its genetic structure. A viable alternative would be to collect adults in flowers, a procedure that allows sampling of both males and females, as all adult bees search for nectar as a food supply. Due to the ease of collecting males with artificial baits and the difficulties of locating nests in nature, female and nesting biology are unknown in 30\% (Ramírez et al., 2002) and $80 \%$ (Cameron, 2004), respectively, of all Euglossini species.

Even though the biological data point to a high degree of dispersion, literature about the occurrence of diploid males in natural populations of euglossine bees appears contradictory. High frequencies of diploid males have been described in populations of different species in Panama (Roubik et al., 1996; Zayed et al., 2004) and Colombia (LópezUribe et al., 2007), but not in samples from Brazil (Takahashi et al., 2001). The presence of $2 \mathrm{n}$ males has been associated with reduced population size caused by habitat fragmentation due to human activities (Zayed and Packer, 2005). Because of their inviability or sterility, diploid males represent a heavy genetic burden for their populations. For this reason, the occurrence of diploid males has been identified as a cause of the simpler social organisation found in this tribe compared to other eusocial corbiculate bees (Roubik et al., 1996). In addition, the high frequency of euglossine diploid males has conferred credibility to the proposition of an extinction vortex for Hymenoptera populations because of their peculiar sex determination system (Zayed et al., 2004; Zayed and Packer, 2005).

Considering the increasing importance of cities as refuges for bee populations, this work aimed to determine the genetic structure of $E u$ glossa cordata urban populations, analysing males and females collected in Thevetia peruviana (Apocynaceae) flowers in 11 cities over a north-south transect in São Paulo state. The analysis of 15 allozyme and 9 microsatellite loci showed that genetic differentiation among populations is low, indicating a high degree of dispersion in this bee species.

\section{MATERIAL AND METHODS}

\subsection{Sampling}

A total of 705 individuals of $E$. cordata were collected from urban areas of 11 cities in São Paulo state (Brazil) (Fig. 1 and Tab. I).

Males and females of E. cordata were captured with a plastic bag while visiting flowers of Thevetia peruviana (Apocynaceae) to collect nectar. In Bertioga, the samples were collected with attractive baits (cineole and vanillin), and therefore, only males were sampled. Captured individuals were identified, placed in plastic tubes on ice and then kept at $-20{ }^{\circ} \mathrm{C}$ until the analyses were performed.

Individuals from Rifaina, Pedregulho, São Carlos and some individuals from Jaboticabal were collected between 2004 and 2006. Samples from Franca, Ribeirão Preto, Araraquara, Leme, Rio Claro, Piracicaba, Bertioga and part of the sample from Jaboticabal were obtained between 2007 and 2009. In each city, at least five urban sites were sampled to maintain a better representation of the population living there.

\subsection{Genetic analysis}

Genomic DNA was extracted from the third pair of legs from each individual, using a $10 \%$ Chelex protocol (Walsh et al., 1991) or the phenolchloroform protocol (Sheppard and McPheron, 1991). Both procedures gave the same results in microsatellite analysis, but we preferred to use the latter method when the samples were used for mtDNA analysis too.

Analysis of the allozyme loci was performed primarily to differentiate $E$. cordata individuals from morphologically similar species, Euglossa securigera and Euglossa townsendi, according to patterns described by López-Uribe and Del Lama (2007). In addition, this method was used to estimate the intra- and interpopulational variation. Electrophoretic analysis was conducted for the following enzymes: acid phosphatase (Acp), esterase1 and esterase-4 (Est-1 and Est-4, respectively), 


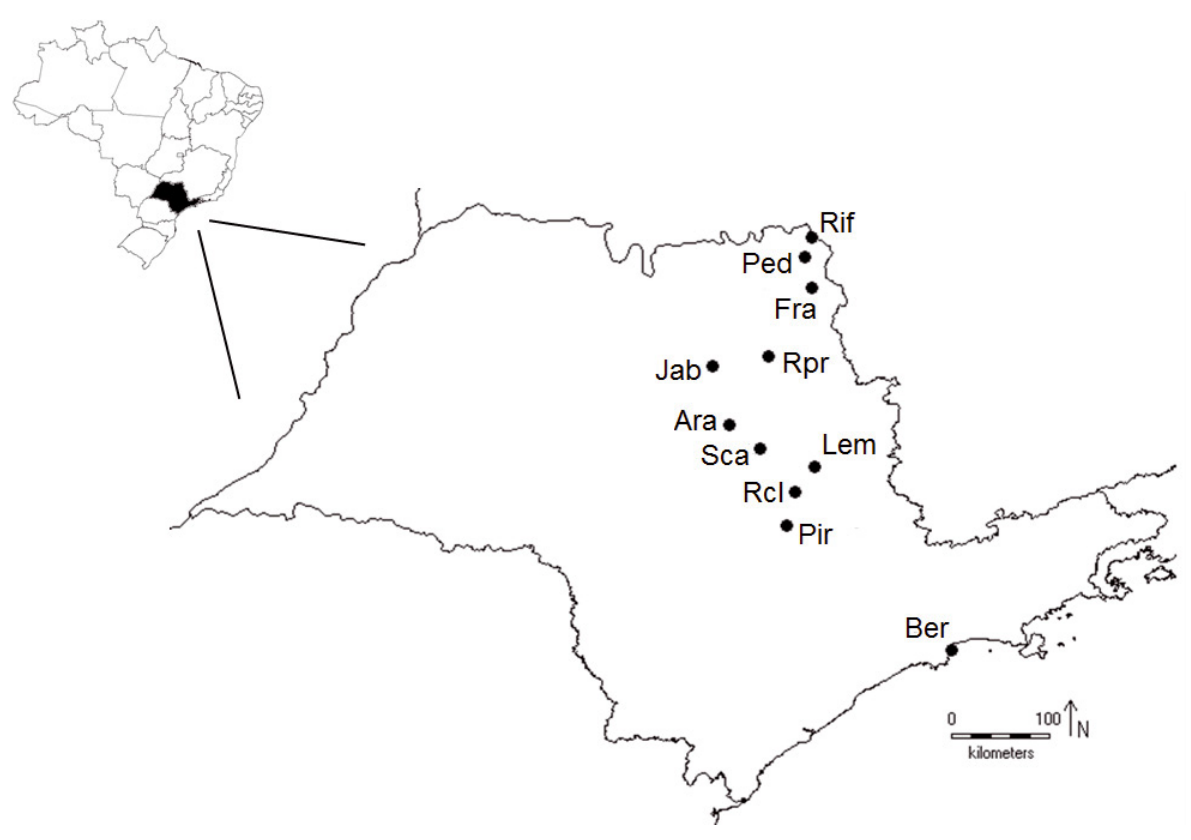

Figure 1. Map of the state of São Paulo showing the localities inside urban areas where males and females of Euglossa cordata were sampled. The sampling sites (codes) were described in the legend of Table I.

Table I. Data on samples of Euglossa cordata, including sampling sites and their geographical coordinates and codes, number $(\mathrm{N})$ of bees $(\mathrm{M}=$ males and $\mathrm{F}=$ females $)$ captured, and number of individuals analyzed for allozymes (alloz) or microsatellites (micrst) loci.

\begin{tabular}{lcccccc} 
& & & \multicolumn{3}{c}{$\mathrm{N}$} & \multicolumn{2}{c}{ Sample size } \\
\cline { 3 - 7 } Locality & Coordinates & Code & $\mathrm{M}$ & $\mathrm{F}$ & alloz & micrst \\
\hline Rifaina & $20^{\circ} 05^{\prime} \mathrm{S} 47^{\circ} 25^{\prime} \mathrm{W}$ & Rif & - & 94 & 89 & 94 \\
Pedregulho & $20^{\circ} 16^{\prime} \mathrm{S} 47^{\circ} 27^{\prime} \mathrm{W}$ & Ped & - & 28 & 28 & 28 \\
Franca & $20^{\circ} 32^{\prime} \mathrm{S} 47^{\circ} 24^{\prime} \mathrm{W}$ & Fra & 1 & 32 & 33 & 33 \\
Ribeirão Preto & $21^{\circ} 10^{\prime} \mathrm{S} 47^{\circ} 48^{\prime} \mathrm{W}$ & $\mathrm{Rpr}$ & 9 & 55 & 64 & 64 \\
Jaboticabal & $21^{\circ} 01^{\prime} \mathrm{S} 48^{\circ} 04^{\prime} \mathrm{W}$ & $\mathrm{Jab}$ & 11 & 42 & 35 & 53 \\
Araraquara & $21^{\circ} 47^{\prime} \mathrm{S} 48^{\circ} 10^{\prime} \mathrm{W}$ & Ara & 5 & 60 & 64 & 65 \\
São Carlos & $22^{\circ} 00^{\prime} \mathrm{S} 47^{\circ} 53^{\prime} \mathrm{W}$ & Sca & 3 & 123 & 97 & 126 \\
Leme & $22^{\circ} 11^{\prime} \mathrm{S} 47^{\circ} 23^{\prime} \mathrm{W}$ & Lem & 18 & 46 & 39 & 64 \\
Rio Claro & $22^{\circ} 24^{\prime} \mathrm{S} 47^{\circ} 33^{\prime} \mathrm{W}$ & Rcl & 7 & 60 & 67 & 67 \\
Piracicaba & $22^{\circ} 43^{\prime} \mathrm{S} 47^{\circ} 38^{\prime} \mathrm{W}$ & Pir & 31 & 37 & 67 & 68 \\
Bertioga & $23^{\circ} 51^{\prime} \mathrm{S} 46^{\circ} 08^{\prime} \mathrm{W}$ & Ber & 43 & - & 43 & 43 \\
\hline
\end{tabular}

isocitric dehydrogenase (Icd), superoxide dismutase (Sod), fumarase (Fum), glucose phosphate isomerase (Gpi) and 6-phosphogluconate dehydrogenase (6Pgd) in tris-citric acid buffer, $\mathrm{pH}$ 7.5. Tris-citric acid buffer, $\mathrm{pH} 8.0$, was used for electrophoretic analysis of cytosolic and mitochondrial malate dehydrogenases (cMdh and mMdh), phosphoglucomutase (Pgm), $\alpha$-glycerophosphate dehy- drogenase ( $\alpha \mathrm{Gpdh}), \beta$-hydroxybutyrate dehydrogenase $(\beta \mathrm{Hbdh})$, hexokinase (Hk) and malic enzyme $(\mathrm{Me})$.

For the microsatellite analysis, nine pairs of species-specific Euglossa cordata oligos (17, 18, $30 \mathrm{~b}, 51,35,24,26,30 \mathrm{a}$ and 37), designed by Souza et al. (2007), were used. Amplification by polymerase chain reaction (PCR) was performed 
according to the protocol described by these authors, and the products generated were resolved in a MegaBACE-750 (GE) fragment analyser, using the program MegaBACE fragment profiler.

\subsection{Data analysis}

Genetic variability of each population was determined: (i) through the number of alleles (A), considering data from males and females; (ii) the observed ( $\mathrm{Ho})$ and expected $(\mathrm{He})$ heterozygosities and (iii) by the inbreeding coefficient (Fis), estimated from female data only. These parameters were calculated using FSTAT 2.9.3.2 (Goudet, 1995).

To assess the genetic differentiation levels among populations, the software Arlequin 3.1 was used (Excoffier et al., 2005) to estimate the Fst parameter of the F-statistics, according to Weir and Cockerham (1984), and the partition of the genetic variation within and among populations by Analysis of Molecular Variance (AMOVA).

As microsatellites are highly polymorphic markers, Fst and AMOVA values were separately estimated from the loci with higher (loci 17, 18, 24, 26 and 37) and lower (loci 35 and 51) heterozygosity levels and compared with their values when all loci were considered together to see if the sample size used in the microsatellite analysis was suitable.

For all markers, one locus was considered polymorphic when the frequency of the most common allele was smaller than $95 \%$. Statistical tests were performed using a significance level of $5 \%$.

\section{RESULTS}

\subsection{Gene variation}

Allozyme phenotypes were determined for 626 individuals from the 11 sampling sites, and all were identified as described by LópezUribe and Del Lama (2007). Of the 15 loci analysed, with $2 \%$ missing data, five were monomorphic, and 10 showed electrophoretic enzyme variants, but only two loci exhibited polymorphism at the $95 \%$ criterion, Est 1 and $c M d h$.

A total of 705 individuals from the 11 sampling sites were genotyped for nine microsatellite loci. All loci showed polymorphism, with an average of 16.56 alleles per locus. The absence of amplification or a poor amplification in some individuals and at some loci generated a rate of $4.7 \%$ of missing data.

Population number of alleles (A), obtained from allozyme and microsatellite loci analysis, are presented in Table II. The estimation of inbreeding was made by comparing observed and expected heterozygosities from female samples (Tab. II).

\subsection{Population differentiation}

Differentiation among populations was investigated first by the Fst values obtained from allozyme polymorphic loci, Est-1 and $c M d h$ (Tab. III). The analysis revealed significant genetic differentiation for Est-1 (Fst = 0.04), $c M d h($ Fst $=0.02)$ and the mean Fst averaged over all loci (Fst $=0.03)$, but when we excluded the sample from Bertioga from this analysis, significant genetic differentiation was observed only for the locus Est-1 (Fst $=0.04)$.

The same analysis was performed for the microsatellite loci (Tab. III). Considering the eleven populations studied, the average Fst was not significant. Excluding the sample from Bertioga from the analysis, some Fst values were no longer significant for two of the analysed loci (loci 18 and 26), confirming the higher genetic homogeneity among the populations of the transect.

Data from microsatellite loci were also used for the Analysis of Molecular Variance (AMOVA). As shown in Table IV, the partition of the variation among the three hierarchical levels showed that the populations are homogeneous with each other (Fst $=0.0031$, $P>0.05)$, although there was considerable variation among individuals within population (Fst $=0.056, P<0.05$ ) and within individuals (Fst $=0.941, P<0.05)$.

The AMOVA analysis gave non-significant results when loci with higher $($ Fst $=0.0041$; $P=0.73$ ) or lower (Fst $=-0.00072 ; P=$ 1.0) heterozygosities are considered separately, strengthening the accuracy of the Fst averaged over all loci (Tab. IV). 
Table II. Number of alleles (A) and observed heterozygosity (Ho) at allozyme and microsatellite loci in Euglossa cordata populations from Rifaina (Rif), Pedregulho (Ped), Franca (Fra), Ribeirão Preto (Rpr), Jaboticabal (Jab), Araraquara (Ara), São Carlos (Sca), Leme (Lem), Rio Claro (Rcl), Piracicaba (Pir) and Bertioga (Ber). $\mathrm{N}=$ number of individuals (females + males). Values in bold indicate populations with significant inbreeding coefficient (Fis).

\begin{tabular}{|c|c|c|c|c|c|c|c|c|c|c|c|c|}
\hline \multicolumn{13}{|c|}{ Populations } \\
\hline Loci & & Rif & Ped & Fra & Rpr & Jab & Ara & Sca & Lem & Rcl & Pir & Ber \\
\hline \multirow{3}{*}{17} & $\mathbf{A}$ & 12 & 11 & 11 & 12 & 11 & 14 & 11 & 14 & 13 & 12 & 10 \\
\hline & $\mathbf{N}$ & $92+0$ & $28+0$ & $32+1$ & $53+7$ & $38+10$ & $60+4$ & $116+3$ & $44+18$ & $60+7$ & $36+26$ & $0+42$ \\
\hline & Ho & 0.902 & 0.75 & 0.875 & 0.868 & 0.868 & 0.833 & 0.853 & 0.841 & 0.833 & 0.778 & - \\
\hline \multirow{3}{*}{8} & $\overline{\mathbf{A}}$ & 13 & 13 & 13 & 13 & 13 & 13 & 13 & 12 & 13 & 12 & 8 \\
\hline & $\mathbf{N}$ & $93+0$ & $28+0$ & $31+1$ & $51+8$ & $42+11$ & $56+4$ & $122+3$ & $44+18$ & $57+6$ & $34+28$ & $0+42$ \\
\hline & Ho & 0.86 & 0.929 & 0.935 & 0.922 & 0.929 & 0.964 & 0.902 & 0.886 & 0.93 & 1 & - \\
\hline \multirow{3}{*}{ 30b } & $\overline{\mathbf{A}}$ & 18 & 11 & 11 & 14 & 17 & 17 & 19 & 20 & 14 & 13 & 13 \\
\hline & $\mathbf{N}$ & $88+0$ & $27+0$ & $31+1$ & $51+8$ & $39+10$ & $55+4$ & $108+3$ & $39+18$ & $56+5$ & $36+25$ & $0+34$ \\
\hline & Ho & 0.784 & 0.778 & 0.806 & 0.902 & 0.795 & 0.782 & 0.787 & 0.821 & 0.75 & 0.806 & - \\
\hline \multirow{3}{*}{35} & $\overline{\mathbf{A}}$ & 5 & 4 & 5 & 6 & 4 & 7 & 6 & 6 & 6 & 7 & 5 \\
\hline & $\mathbf{N}$ & $93+0$ & $28+0$ & $31+1$ & $55+9$ & $42+11$ & $60+3$ & $121+3$ & $46+18$ & $60+7$ & $37+29$ & $0+42$ \\
\hline & Ho & 0.41 & 0.5 & 0.419 & 0.545 & 0.405 & 0.533 & 0.529 & 0.587 & 0.5 & 0.595 & - \\
\hline \multirow{3}{*}{51} & $\mathbf{A}$ & 8 & 6 & 4 & 6 & 5 & 5 & 6 & 5 & 7 & 6 & 3 \\
\hline & $\mathbf{N}$ & $93+0$ & $28+0$ & $32+1$ & $54+7$ & $42+11$ & $60+4$ & $119+3$ & $46+18$ & $60+7$ & $36+26$ & $0+43$ \\
\hline & Ho & 0.452 & 0.464 & 0.438 & 0.685 & 0.548 & 0.533 & 0.496 & 0.391 & 0.583 & 0.389 & - \\
\hline \multirow{3}{*}{24} & $\overline{\mathbf{A}}$ & 17 & 11 & $\overline{9}$ & 13 & 11 & 13 & 13 & 12 & 10 & 15 & 6 \\
\hline & $\mathbf{N}$ & $92+0$ & $28+0$ & $32+1$ & $52+8$ & $41+11$ & $59+5$ & $114+1$ & $45+18$ & $60+7$ & $34+26$ & $0+43$ \\
\hline & Ho & 0.685 & 0.75 & 0.594 & 0.75 & 0.732 & 0.576 & 0.711 & 0.733 & 0.683 & 0.765 & - \\
\hline \multirow{3}{*}{26} & $\mathbf{A}$ & 12 & 8 & 12 & 13 & 11 & 10 & 11 & 12 & 12 & 15 & 7 \\
\hline & $\mathbf{N}$ & $93+0$ & $28+0$ & $32+1$ & $52+9$ & $41+10$ & $59+5$ & $104+1$ & $45+18$ & $59+7$ & $35+29$ & $0+43$ \\
\hline & Ho & 0.81 & 0.75 & 0.781 & 0.827 & 0.732 & 0.644 & 0.808 & 0.844 & 0.746 & 0.886 & - \\
\hline \multirow{3}{*}{ 30a } & $\bar{A}$ & $\overline{10}$ & 6 & $\overline{6}$ & 8 & 8 & 9 & 7 & 8 & 9 & 10 & 7 \\
\hline & $\mathbf{N}$ & $89+0$ & $27+0$ & $31+1$ & $50+9$ & $42+11$ & $60+5$ & $75+1$ & $46+18$ & $60+7$ & $35+28$ & $0+42$ \\
\hline & Ho & 0.719 & 0.593 & 0.581 & 0.48 & 0.548 & 0.583 & 0.667 & 0.63 & 0.533 & 0.629 & - \\
\hline \multirow{3}{*}{37} & $\mathbf{A}$ & 20 & 11 & 11 & 11 & 14 & 14 & 14 & 12 & 19 & 9 & 9 \\
\hline & $\mathbf{N}$ & $92+0$ & $28+0$ & $32+1$ & $52+9$ & $42+11$ & $60+5$ & $110+1$ & $46+18$ & $60+7$ & $35+27$ & $0+41$ \\
\hline & Ho & 0.728 & 0.821 & 0.594 & 0.712 & 0.714 & 0.683 & 0.655 & 0.696 & 0.65 & 0.714 & - \\
\hline \multirow[t]{3}{*}{ Est-1 } & $\mathbf{A}$ & 3 & 3 & 1 & 2 & 1 & 3 & 3 & 3 & 3 & 2 & 3 \\
\hline & $\mathbf{N}$ & $86+3$ & $28+1$ & $32+1$ & $55+9$ & $24+11$ & $59+5$ & $96+26$ & $37+2$ & $60+7$ & $37+31$ & $0+43$ \\
\hline & Ho & 0.053 & 0.103 & 0 & 0.036 & 0 & 0.153 & 0.063 & 0.081 & 0.083 & 0.081 & - \\
\hline \multirow[t]{3}{*}{$c M d h$} & $\mathbf{A}$ & 2 & 2 & 2 & 2 & 2 & 2 & 2 & 2 & 2 & 2 & 1 \\
\hline & $\mathbf{N}$ & $86+3$ & $28+1$ & $32+1$ & $55+9$ & $24+11$ & $59+5$ & $96+26$ & $37+2$ & $60+7$ & $37+31$ & $0+43$ \\
\hline & Ho & 0.242 & 0.414 & 0.375 & 0.31 & 0.333 & 0.169 & 0.197 & 0.297 & 0.283 & 0.297 & - \\
\hline
\end{tabular}

\subsection{Diploid male analysis}

Allozyme and microsatellite genotypes allowed the identification of the presence of diploid males in these E. cordata populations. 139 males were analysed for the allozyme loci, and for the microsatellite loci, 177 males were analysed. Only one diploid male from Rifaina was detected by its heterozygous condition in 7 of 9 microsatellite loci analysed. The al- lozyme analysis did not reveal the presence of diploid males.

\section{DISCUSSION}

This is the first effort to assess the genetic structure of euglossine bee populations sampled inside urban environments using allozyme and microsatellite analysis. It is also 
Table III. Genetic differentiation (Fst) among populations measured by the distance method (Weir and Cockerham, 1984) viewed through the Est-1 and $c M d h$ loci or through nine microsatellite loci. Average values over all allozyme (Mean A) or microsatellite loci (Mean M) are also estimated considering all populations (A) or excluding the samples from Bertioga (B). Significant values of Fst are denoted with bold characters.

\begin{tabular}{ccc}
\hline Loci & $\mathrm{A}$ & $\mathrm{B}$ \\
\hline$E s t-1$ & $\mathbf{0 . 0 4}$ & $\mathbf{0 . 0 4}$ \\
$c M d h$ & $\mathbf{0 . 0 2}$ & 0.008 \\
Mean A & $\mathbf{0 . 0 3}$ & 0.02 \\
\hline 17 & $\mathbf{0 . 0 0 3 5}$ & $\mathbf{0 . 0 0 3 5}$ \\
18 & $\mathbf{0 . 0 0 6}$ & 0.0017 \\
$30 b$ & $\mathbf{0 . 0 0 7}$ & 0.0014 \\
35 & 0 & 0 \\
51 & 0.003 & 0.0032 \\
24 & 0.0025 & 0.0006 \\
26 & $\mathbf{0 . 0 0 7}$ & $\mathbf{0 . 0 0 6 5}$ \\
$30 a$ & $\mathbf{0 . 0 1 3}$ & $\mathbf{0 . 0 1 1}$ \\
37 & $\mathbf{0 . 0 1 1}$ & $\mathbf{0 . 0 0 7 3}$ \\
Mean M & 0.003 & 0.0015 \\
\hline
\end{tabular}

the first female-based study of euglossine population genetics. As expected, the number of alleles, the intralocus heterozygosity values and the heterozygosity averaged over all loci were higher with microsatellite loci than with allozymes.

Most of the loci in the studied populations were consistent with genetic equilibrium. However, for some loci and some localities, there was a significant deficit of heterozygotes. This reduction has usually been attributed to null alleles, selection, population subdivision (Wahlund effect) or inbreeding, among other factors (Hartl and Clark, 2007).

All but one male submitted to analysis showed one allele per locus, which means that the presence of null alleles was not the cause of the observed deficit of heterozygotes. As the microsatellite loci are considered neutral markers (McKay and Latta, 2002; Porcher et al., 2006), it is expected that this lack would not be due to strong selective pressures. The observed genetic homogeneity among populations also excludes population subdivision as its cause. High levels of inbreeding are not expected when we consider the low number of detected diploid males in the samples; otherwise, inbreeding effects are expected over all loci and populations (Hartl and Clark, 2007). Further analyses are required to find an alternative explanation for this deficit.

As the Fst and AMOVA values obtained when all loci were considered together were similar to those values when the microsatellite loci were grouped according to their heterozygosity level, we can conclude that our results were not limited or strongly biased by our sample size.

The interpopulational differentiation analysis through allozyme and microsatellite loci revealed that populations are genetically homogeneous (Fst values are not significant when averaged over all loci). However, significant pairwise Fst values were found (data not shown) in most of the comparisons between Bertioga and the other populations, which was expected because this sample was different in several ways. It was collected using attractive compounds, so only males were captured. This site was in an area situated in the Atlantic forest edges, not an urban environment, and was situated outside the transect. Although the sample from the Bertioga population was included only as a reference to the populations of the transect, its inclusion did not produce significant population structuring, which confirms the strong gene flow due to the high dispersion of euglossine bees (Janzen, 1971; Dressler, 1982; Dick et al., 2004; Roubik and Hanson, 2004).

Allozyme and microsatellite data also showed that E. cordata diploid males were rare within the populations sampled. The data described here and in our previous studies (Takahashi et al., 2001; Souza et al., unpubl. data) identified only one diploid among about 300 males of $E$. cordata analysed and only three diploid males out 1500 males of 26 species of four Euglossini genera analysed. Our results are very different from data reported in other allozyme studies (Roubik et al., 1996; Zayed et al., 2004; López-Uribe et al., 2007). If these differences are real, the diploid male frequencies found must be attributed to particular biological and genetic traits and historical and demographical features of each 
Table IV. Analysis of Molecular Variance (AMOVA) using data from microsatellite loci with higher (A) or lower (B) heterozygosity levels and all loci considered together, showing the distribution of the variation within and among populations. Significant values $(P<0.05)$ are denoted with bold characters.

\begin{tabular}{lccc}
\hline & A & B & All loci \\
\hline Source of variation & \% variation & \% variation & \% variation \\
\hline Among populations & 0.41 & -0.072 & 0.31 \\
Among individuals within pop & $\mathbf{5 . 6}$ & $\mathbf{6 . 9 5}$ & $\mathbf{5 . 6 2}$ \\
Within individuals & $\mathbf{9 4 . 2 3}$ & $\mathbf{9 3 . 1 3}$ & $\mathbf{9 4 . 0 6}$ \\
\hline
\end{tabular}

population studied and further research is required to identify them.

The few studies on population genetics of Euglossini populations have been performed on samples collected from forests or forest fragments (Zayed et al., 2004; Sofia et al., 2005; Suzuki et al., 2010); this is the first one in which urban populations were analysed. As urbanisation causes environmental fragmentation (Niemelä, 2000; Cane, 2005; Zanette et al., 2005), it is expected that urban populations would be under a stronger genetic drift and exhibit reduced population effective size, conditions that favour matings between relatives, allelic loss in the sexual locus (csd) and diploid male production (Cook and Crozier, 1995; van Wilgenburg et al., 2006). Our data indicate that, although $E$. cordata populations are subject to the damaging effects of human actions, their genetic structure suggests an unexpected degree of genetic health and resistance to these effects.

Data shown here give a positive diagnosis about the genetic health of these E. cordata populations. This does not mean that environmental issues relating to conservation concerns over the decline of pollinators do not deserve the attention that has been given to them. If this is the genetic condition of other Euglossini species, this issue will certainly be addressed when similar studies are conducted with other euglossine species.

There are at least three reasons to believe that our analysis is robust: (i) the number of individuals and samples analysed; (ii) the number of microsatellite loci under analysis and (iii) the similar results obtained when microsatellite data were analysed together or separately in groups of loci with greater or lesser heterozygosity levels. Therefore, we can say that these E. cordata populations have high genetic diversity, usually are in genetic equilibrium, have low population structuring and have rare diploid males; consequently, high gene flow and effective population size $(\mathrm{Ne})$ can be inferred.

Our results are in agreement with reports that these bees fly long distances (Janzen, 1971) and with phylogeographic evidences of long-distance dispersal of South American Euglossini species (Dick et al., 2004), and they reveal a different picture than what has been described by other authors (Zayed et al., 2004; Zayed and Packer, 2005). The observed low differentiation among populations may be primarily dependent on the male ability to disperse, if we take into account the suggested philopatric behaviour of females (Garófalo, 1992; Santos and Garófalo, 1994; Cameron and Ramírez, 2001; Augusto and Garófalo, 2009). Sex-asymmetrical dispersal in Euglossini species is a matter that should be investigated by comparing genetic differentiation among populations from nuclear genes (inherited from both parents) and mitochondrial genes (inherited from one parent).

\section{ACKNOWLEDGEMENTS}

We thank the FAPESP agency for the fellowship to NCMC (2006/59387-8) and the financial support to this project (2004/15801-0). Thanks are also due to Isabel C. Godoy for technical help, to Norma Mortari for laboratory setting courtesy and to Camilla H. da Silva, Juliano C. Almeida and Otávio L. e Silva for help in sampling. We gratefully acknowledge two anonymous referees for their comments and suggestions.

Différenciation génétique des populations urbaines d'Euglossa cordata de l'État de Sao Paulo, Brésil. 
diversité génétique / flux génique / Euglossines / microsatellites / allozymes

\section{Zusammenfassung - Genetische Differenzierung von urbanen Populationen von Euglossa corda-} ta aus dem Staat São Paulo, Brasilien. In dieser Arbeit untersuchen wir die genetische Struktur von elf urbanen Populationen von Euglossa cordata aus dem Staat São Paulo in Brasilien (Abb. 1). Wir sammelten 705 männliche und weibliche Tiere beim Sammeln von Nektar aus Blüten von Thevetia peruviana (Apocynaceae). Wir extrahierten die gesamte DNA mit 10\% Chelex oder der Phenol-ChloroformMethode, und untersuchten die Variabilität von Mikrosatelliten an neun Loci (17, 18, 30b, 51, 35, 24, 26, 30a and 37) mit Spezies-spezifischen Primern für $E$. cordata. Wir untersuchten auch die elektrophoretische Variabilität der folgenden Enzyme: Acp, Est-1, Est-4, Icd, Sod, Fum, Gpi, 6Pgd, cMdh, $m M d h, P g m, \alpha G p d h, \beta H b d h, H k$ und $M e$.

Die Allozymanalysen wurden an 412 Individuen und 15 Loci durchgeführt, wobei jedoch nur 2 Loci, Est-1 und $c M d h$ polymorph waren (Tab. III). Alle neun Mikrosatellitenloci waren polymorph, mit im Mittel 16.56 Allelen pro Locus bei allen genotypisierten 705 Individuen. Zwischen den Populationen beobachteten wir keine signifikante genetische Differenzierung anhand der über alle Loci gemittelten Fst Werte (Tab. II). Die für drei Hierarchieebenen durchgeführte AMOVA Analyse (Tab. IV) zeigte, dass die Populationen homogen sind, weil der größte Anteil der Variabilität allen Populationen gemeinsam ist. Unter allen 177 untersuchten männlichen Tieren fanden wir ein diploides Männchen. Dies ist die erste Studie über urbane Populationen bei euglossinen Bienen, die weibliche Tiere einschließt; sie ergibt ein positives Bild der genetischen Gesundheit der Populationen von E. cordata. Unsere Daten zeigen, dass urbane Populationen von E. cordata eine hohe genetische Diversität aufweisen, sich im genetischen Gleichgewicht befinden und nicht strukturiert sind. Aus diesen Beobachtungen leiten wir hohen Genfluss und eine umfangreiche effektive Populationsgröße ab. Die geringe genetische Differenzierung zwischen den Populationen könnte stark von der Ausbreitungsfähigkeit der Männchen abhängen, wenn man das offensichtlich ortstreue Verhalten der Weibchen in Betracht zieht. Dieses Ergebnis deutet an, dass das unterschiedliche Ausbreitungsverhalten der Geschlechter weiterer Forschung bedarf.

\section{genetische Diversität / Genfluss / Euglossine Bie-} nen / Mikrosatelliten / Allozyme

\section{REFERENCES}

Augusto S.C., Garófalo C.A. (2009) Bionomics and sociological aspects of Euglossa fimbriata
(Apidae, Euglossini), Genet. Mol. Res. 8, 525538.

Búrquez A. (1997) Distributional limits of euglossine and meliponine bees (Hymenoptera: Apidae) in northwestern Mexico, Pan-Pac. Entomol. 73, 137140.

Cameron S.A. (2004) Phylogeny and biology of Neotropical orchid bees (Euglossini), Annu. Rev. Entomol. 49, 377-404.

Cameron S.A., Ramírez S. (2001) Nest architecture and nesting ecology of orchid bee Eulaema meriana (Hymenoptera: Apidae: Euglossini), J. Kans. Entomol. Soc. 74, 142-165.

Cancine A.D.M., Damon A. (2007) Fragrance analysis of Euglossini bee pollinated orchids from Soconusco, South-East Mexico, Plant Species Biol. 22, 127-132.

Cane J.H. (2005) Bees needs challenged by urbanization, in: Johnson E.A., Klemens M.W. (Eds.), Nature in fragments: The legacy of sprawl, Columbia University Press, New York, pp. 109124.

Cook J.M., Crozier R.H. (1995) Sex determination and population biology in the Hymenoptera, Tree 10, 281-286.

Dick C.W., Roubik D.W., Gruber K.F., Bermingham E. (2004) Long distance gene flow and cross-Andean dispersal of lowland rainforest bees (Apidae: Euglossini) revealed by comparative mitochondrial DNA phylogeography, Mol. Ecol. 13, 37753785.

Dressler R.L. (1982) Biology of the orchid bees (Euglossini), Annu. Rev. Ecol. Syst. 13, 373-394.

Eltz T., Roubik D.W., Whitten M.W. (2003) Fragrances, male display and mating behavior of Euglossa hemichlora - a flight cage experiment, Physiol. Entomol. 28, 251-260.

Excoffier L., Laval G., Schneider S. (2005) Arlequin 3.1: An integrated software package for population genetics data analysis, Evol. Bioinform. Online 1, 47-50.

Farias R.C.A.P., Madeira da Silva M.C., PereiraPeixoto M.H., Martins C. (2008) Composição e sazonalidade de espécies de Euglossina (Hymenoptera: Apidae) em mata e duna na Área de Proteção Ambiental da Barra do Rio Mamanguape, Rio Tinto, PB, Neotrop. Entomol. 37, 253-258.

Garófalo C.A. (1992) Comportamento de nidificação e estrutura de ninhos de Euglossa cordata (Hymenoptera: Apidae: Euglossini), Rev. Bras. Biol. 52, 187-198.

Goudet J. (1995) FSTAT, a program to estimate and test gene diversities and fixation indices (version 2.9.3.2), J. Hered. 86, 485-486.

Grixti J.C., Wonga L.T., Cameron S.A., Favreta C. (2009) Decline of bumble bees (Bombus) in the North American Midwest, Biol. Conserv. 142, 7584. 
Guimarães E., Di Stasi L.C., Maimoni-Rodella R.C.S. (2008) Pollination biology of Jacaranda oxyphylla with an emphasis on staminode function, Ann. Bot. 102, 699-711.

Hartl D.L., Clark A.G. (2007) Principles of Population Genetics, 4th ed., Sinauer, Sunderland, MA.

Janzen D.H. (1971) Euglossine bees as long-distance pollinators of tropical plants, Science 171, 203205.

López-Uribe M.M., Del Lama M.A. (2007) Molecular identification of females of Euglossa spp. Latreille (Hymenoptera: Apidae: Euglossini) floral visitors of Thevetia peruviana (Apocynaceae) in urban areas, Neotrop. Entomol. 36, 712-720.

López-Uribe M.M., Almanza M.T., Marina Ordoñez M. (2007) Diploid male frequencies in Colombian populations of euglossine bees, Biotropica 39, 660-662.

López-Uribe M.M., Oi C.A., Del Lama M.A. (2008) Nectar-foraging behavior of Euglossine bees (Hymenoptera: Apidae) in urban areas, Apidologie 39, 410-418.

McKay J.K., Latta R.G. (2002) Adaptive population divergence: markers, QTL, and traits, Tree 17, 285-291.

Niemelä J. (2000) Is there a need for a theory of urban ecology? Urban Ecosyst. 3, 57-65.

Oliveira M.L. (2006) Três novas espécies de abelhas da Amazônia pertencentes ao gênero Eulaema (Hymenoptera: Apidae: Euglossini), Acta Amazonica 36, 121-128.

Oliveira M.L., Nemésio A. (2003) Exaerete lepeletieri (Hymenoptera: Apidae: Euglossina): a new cleptoparasitic bee from Amazônia, Lundiana 4, 117120.

Porcher E., Giraud T., Lavigne C. (2006) Genetic differentiation of neutral markers and quantitative traits in predominantly selfing metapopulations: confronting theory and experiments with Arabidopsis thaliana, Genet. Res. 87, 1-12.

Ramírez S., Dressler R.L., Ospina M. (2002) Abejas euglossinas (Hymenoptera: Apidae) de la región neotropical: listado de especies con notas sobre su biología, Biota Colomb. 3, 7-118.

Rasmussen C. (2009) Diversity and abundance of orchid bees (Hymenoptera: Apidae, Euglossini) in a tropical rainforest sucession, Neotrop. Entomol. 38, 66-73.

Roubik D.W., Hanson P.E. (2004) Orchid bees from tropical America: biology and field guide. INBio Press, Santo Domingo de Heredia, Costa Rica.

Roubik D.W., Weight L.A., Bonilla M.A. (1996) Population genetics, diploid males, and limits to social evolution of euglossine bees, Evolution 50, 931-935.
Sandino J.C. (2004) Are there any agricultural effects on the capture rates of male euglossine bees (Apidae: Euglossini)? Rev. Biol. Trop. 52, 115118.

Santos M.L., Garófalo C.A. (1994) Nesting biology and nest re-use of Eulaema nigrita (Hymenoptera: Apidae, Euglossini), Insectes Soc. 41, 91-110.

Sheppard W.S., McPheron B.A. (1991) Ribosomal DNA diversity in Apidae, in: Smith D.R. (Ed.), Diversity in the genus Apis, Westview, Boulder (CO), pp. 89-102.

Sofia S.H., Paula F.M., Santos A.M., Almeida F.S., Sodré L.M.K. (2005) Genetic structure analyses of Eufriesea violacea (Hymenoptera, Apidae) populations from southern Brazilian Atlantic rainforest remnants, Genet. Mol. Biol. 28, 479-484.

Souza R.O., Cervini M., Del Lama M.A., Paxton R.J. (2007) Microsatellite loci for euglossine bees (Hymenoptera: Apidae), Mol. Ecol. Notes 6, 1352-1356.

Suzuki K.M., Arias M.C., Giangarelli D.C., Freiria G.A., Sofia S.H. (2010) Mitochondrial DNA diversity of orchid bee Euglossa fimbriata (Hymenoptera: Apidae) populations assessed by PCR-RFLP, Biochem. Genet. 48, 326-341.

Takahashi N.C., Peruquetti R.C., Del Lama M.A., Campos L.A.O. (2001) A reanalysis of diploid male frequencies in euglossine bees (Hymenoptera: Apidae), Evolution 55, 1897 1899.

van Wilgenburg E., Driessen G., L.W., Beukeboom L.W. (2006) Single locus complementary sex determination in Hymenoptera: an "unintelligent" design, Front. Zool. 3, 1-15.

Walsh P.S., Metzger D.A., Higuchi R. (1991) Chelex ${ }^{\circledR}$ 100 as a medium for simple extraction of DNA for PCR-based typing from forensic material, BioTech. 10, 506-513.

Weir B., Cockerham C. (1984) Estimating F-statistics for the analysis of population structure, Evolution 38, 1358-1370.

Zanette L.R.S., Martins R.P., Ribeiro S.P. (2005) Effects of urbanization on Neotropical wasp and bee assemblages in a Brazilian metropolis, Landscape Urban Plan. 71, 105-121.

Zayed A., Packer L. (2005) Complementary sex determination substantially increases extinction proneness of haplodiploid populations. Proc. Natl. Acad. Sci. 102, 10742-10746.

Zayed A., Roubik D.W., Packer L. (2004) Use of diploid male frequency data as an indicator of pollinator decline. Proc. R. Soc. Lond. B 271, S9S12. 